\title{
Relevance of In-service-Teacher Training in Tanzania: Lessons from Licensed and Normal Trained Teachers
}

\author{
Benjamin Mbeba Meli \\ Dares Salaam University College of Education \\ Faculty of Humanities and Social sciences, \\ Department of History, political Science and Development Studies \\ P.o Box 2329 Dares Salaam Tanzania, East Africa \\ Email: benjaminmbeba@gmail.com
}

\begin{abstract}
The focus of this paper is to examine the efficacy of various in-service teacher training programs offered to both licensed and normal trained teachers in Tanzania. The in-service programs includes effective ways of improving teaching performance for in-service training students, types of in-service teacher training offered to both licensed and normal trained teachers, self-initiatives taken by both types of teachers to undergo in-service training, challenges and problems facing licensed and normal trained teachers, conclusion and recommendations. The paper advances some recommendations that should be taken by the government and other stake-holders to minimize the challenges and problems facing these two types of teachers as far as the education sector in Tanzania are concerned. Key Words: Licensed and Normal Trained Teachers, Pedagogical Skills, In-service Teacher, Teacher training DOI: $10.7176 /$ RHSS/10-6-11

Publication date:March $31^{\text {st }} 2020$

\subsection{Introduction}

In-service training (INSET) is a situation in which teachers have a chance to attain new knowledge and skills in a more dynamic way (Galabawa et al., 2000). The Ministry of Education, Science and Technology (MoEST) in Tanzania has made sure that both licensed and normal trained teachers are getting in-service training courses in order to upgrade their skills and knowledge. Special emphasis was put on licensed trained teachers that by 2010 all licensed trained teachers should have upgraded their levels of education otherwise they will be terminated from their employment. Therefore, the Open University of Tanzania was requested to enrol all licensed trained teachers. It is during INSET where teachers' professional knowledge, professional skills and professional attitudes develop and mature. It is also through INSET that teachers' academic standard is raised, participants acquire skills, attitudes and values intended for particular professionals. The importance of INSET is expressed by Swazin and Monk (2000) who revealed that, INSET which is conducted from areas of work and using facilities which do not really exist in the teachers working places yield very little results. In most cases, teachers fail to transfer knowledge and skills to their students. On the other hand, Linde (1998) suggested that, INSET programs that take place within working places, using the coaching approach, to a large extent yield positive results. Teachers are able to attain and deploy in their classrooms large amount of knowledge and skills acquired. The literature indicates that the good fruits which are expected from INSET depend on the way it is planned and conducted.
\end{abstract}

\subsection{Effective ways of improving Teaching Performance for In-service Training Students}

Teachers' performance is the basic foundation in enhancing quality of education in any society. Teachers whose performance is good always possess knowledge of pedagogy so as to address issues related to classrooms practices (Cochran, 1993; Kanu, 1996). Dunn (1981), Dye (1978) and Meli (2014) support the statement that poor training of the teachers results into teachers' poor performance and the solution for solving that problem is the provision of in-service trainings for teachers.

Osaki (1996) pointed out that good teachers' preparation during in-service training, where skills to create a conducive learning environment and to motivate and improve students self esteem are acquired lead to student achievements in learning. Thus, in order to attain effective training, the in-service training programs must be of high quality of three inter-dependent components namely, facilitators, learners and materials as illustrated in Figure 1 below. 


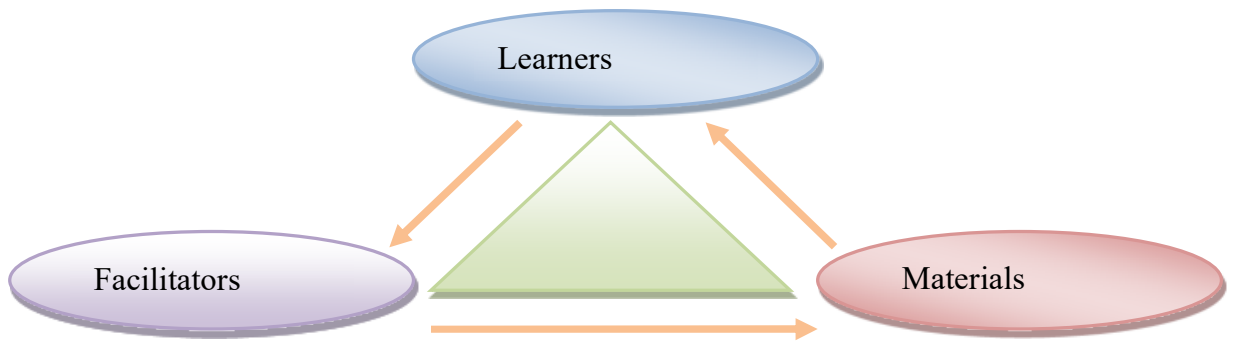

Figure 1: Components for Effective Teacher Education and Training.

Source: Osaki (1996).

Kiwia (1999) revealed that among the problems facing training programs is the facilitator. This problem ranges from experience to mastery of subject matter. The trainers who are mandated to train effective teachers to teach in secondary schools should be competent enough in their subject mastery (Kiwia, 1999) and teachers should acquire the requisite, pedagogical skills during the in-service training. On the other hand, Heyneman and Loxley (1983) pointed out that, in-service training must meet two crucial criteria: first, it must produce learning changes with efficiency and efficacy and secondly, the programs for imparting knowledge for in-service students must be well prepared, and if participants find them entertaining and enjoyable, the chances of learning are greater to occur. Therefore, the training for teachers during in-service training must result in some benefits to teachers, students, schools and the education sector in general. It must be carried out effectively, efficiently and it must create excellence in learning. It further must be employee/teacher centred and more committed to reducing the turnover and grievances of teachers and help them to do their jobs more accurately and efficiently as indicated in figure 2 below.

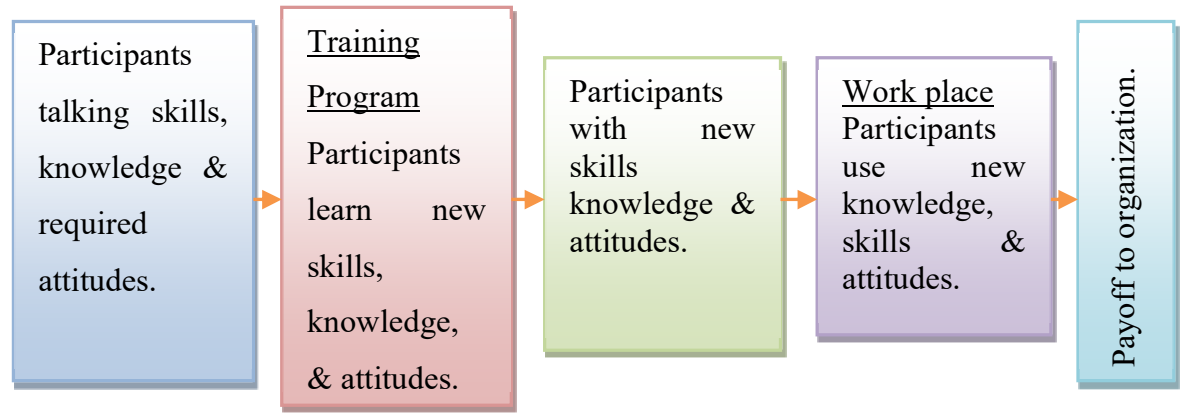

Figure 2: The Logic of Training. Source: Heyneman and Loxley (1983)

Likewise, Joyce and Shower (1988) proposes the main training outcomes if a person attending in-service training as: awareness of education theories and practices, new curriculum; change in attitudes; self role perception changes; academic content; development of skills and the ability to perform discrete behaviours such as designing and delivering questions of various cognitive levels, as well as transfer of training and executive control with consistent and appropriate use of new skills and strategies for classroom instruction.

\subsection{Types of In-service Teacher Training Offered to both Licensed and normal Trained Teachers}

Findings from respondents in the four municipals through interview and focus group discussion showed that both types of teachers had undergone in-service teacher training program depending on the level of their education. However, the costs of the training were not met by the government but by the teachers themselves. What the government did was to aloow them to attend the training. The Municipal Secondary Education Officers interviewed, indicated that their teachers had attended further studies in various programs such as Diploma in Education course, Bachelor degree and Post graduate studies. The main aim of sending them for in-service courses was to make them more competent in teaching skills. On the other hand, one of the Ministry of Education, Science and Technology (MoEST) respondents made the following statement on the importance of sending teachers for in-service training that: 
"...an effective teacher learns as he/she teaches, there is not any type of teacher education that can prepare him/her for the varied experiences he/she faces year to year. Only in-service training can keep a teacher up to date in his/her knowledge, skills, methods and classrooms management. He/she needs in-service training in order to remain effective and successful as a teacher..."

This is in line with Clandinin's (1995) argument that the process of becoming a professional teacher is a "life long process" which usually involves years of acquiring knowledge on teaching, learning process, trying out new teaching style that engage learners, observing others, effective classroom management, good preparation, effective use of teaching and learning materials, receiving and giving feedback. Furthermore, Swazin and Monk (2000: pg?) commenting on the importance of attending in-service teacher training courses argues that:

"....teachers who attend in-service teacher training courses, their academic performance is more than those who do not attend, because it keeps teachers up to date in their knowledge, skills, methods and classrooms management..."

Table 2 and Table 3 below summarize the types of in-service teacher training attended to both types of teachers.

Table 2: Municipal Secondary Education Officers' Responses towards In-Service Teacher Training Courses for Licensed Teachers (2008-2010).

\begin{tabular}{|l|c|c|c|c|}
\hline Municipal/Districts & \multicolumn{4}{|c|}{ Types of Courses Offered } \\
\hline & $\begin{array}{l}\text { Diploma in } \\
\text { Education }\end{array}$ & $\begin{array}{l}\text { Bachelor } \\
\text { Degree } \\
\text { Education }\end{array}$ & $\begin{array}{l}\text { Post Graduate } \\
\text { Studies }\end{array}$ & Total \\
\hline Morogoro & 30 & 46 & 2 & 78 \\
\hline Iringa & 28 & 50 & 3 & 81 \\
\hline Songea & 23 & 45 & 1 & 79 \\
\hline Bunda & 38 & 31 & 1 & 298 \\
\hline Total & 119 & 172 & 07 & 70 \\
\hline
\end{tabular}

Source: Computed from field data (2014).

Table 3: Municipal Secondary Education Officers' Responses towards In-Service Teacher Training Courses for Normal Teachers (2008-2010)

\begin{tabular}{|l|c|l|c|c|}
\hline Municipal/Districts & \multicolumn{4}{|c|}{ Types of Courses Offered } \\
\hline & $\begin{array}{l}\text { Diploma in } \\
\text { Education }\end{array}$ & $\begin{array}{l}\text { Bachelor } \\
\text { Degree in } \\
\text { Education }\end{array}$ & $\begin{array}{l}\text { Post Graduate } \\
\text { Studies }\end{array}$ & Total \\
\hline Morogoro & - & 34 & 14 & 48 \\
\hline Iringa & - & 38 & 18 & 56 \\
\hline Songea & - & 37 & 15 & 52 \\
\hline Bunda & - & 29 & 11 & 40 \\
\hline Total & - & 138 & 58 & 196 \\
\hline
\end{tabular}

Source: Computed from field data (2014).

Table 2 and Table 3 above show that the number of the normal trained teachers who joined in-service teacher training courses for both Bachelor and postgraduate degrees were more than the licensed trained teachers. There were larger numbers of licensed trained teachers who enrolled for degrees in Education than normal teachers. For example, Morogoro municipal had 30 licensed trained teachers who joined Diploma course and 46 licensed trained teachers who enrolled for Bachelor degree against 34 of normal trained teachers who enrolled for the bachelor degree. Iringa municipal had 28 licensed trained teachers who joined for Diploma in Education and another 50 for Bachelor degree. This was different from the normal trained teachers where there was no one enrolled for Diploma in education while there were 38 teachers who were enrolled for Bachelor degree. Songea had 23 licensed trained teachers for Diploma in education and 45 for Bachelor degree, while for the normal trained teachers in the same municipal there were only 37 for Bachelor degree and none enrolled for Diploma course. Bunda municipal indicated that there were 38 licensed trained teachers for Diploma in education and another 31 for Bachelor degree while for normal trained teachers there were only 29 who enrolled for Bachelor degree. However, one of the respondents from headmasters/mistresses commenting on why the licensed trained teachers had joined more in the in-service training than normal trained teachers had this to say: 
..." the government through the Ministry of Education, and Vocational and Training issued directives to licensed trained teachers instructing them that within five years (2004-2009) of starting the program, they are supposed to enrol for further studies (Diploma or Degree courses) and government will sponsor them..."

This was supported by the Coordinator of Induction course for licensed secondary school teachers from the MoEST who commented that:

"within five years (2004-2009) licensed teachers should enrol themselves with the Open University of Tanzania (OUT) for a degree or Diploma program in education and MoEST will sponsor the respective programs". In addition, the respondents were asked why they decided to join in-service programs. Both types of teachers had the following reasons as indicated in Table 3 below.

Table 3: Licensed and Normal Trained Teachers' Responses on why they enrolled for In-Service Teacher Training.

\begin{tabular}{|c|l|c|c|}
\hline $\begin{array}{c}\text { Reasons for Joining In-Service Teacher Training } \\
\text { Courses }\end{array}$ & $\begin{array}{l}\text { Normal Trained } \\
\text { Teachers=30 }\end{array}$ & Licensed Trained Teachers=30 \\
\hline$*$ & $\begin{array}{l}\text { It enables them to design tasks that will } \\
\text { address learners abilities, interests and } \\
\text { needs. }\end{array}$ & 06 & 08 \\
\hline$*$ & $\begin{array}{l}\text { It leads them to develop intellectual Skills } \\
\text { eg: inquiry, problem solving, analysis } \\
\text { and synthesis. }\end{array}$ & 17 & 15 \\
\hline$*$ & $\begin{array}{l}\text { It enables them to know how to organize } \\
\text { learning groups of different abilities. }\end{array}$ & 09 & 11 \\
\hline$*$ & $\begin{array}{l}\text { It enables them to use and emphasize } \\
\text { interactive methods of teaching and } \\
\text { learning. }\end{array}$ & 06 & 08 \\
\hline$*$ & $\begin{array}{l}\text { It enables them to increase salary, } \\
\text { promotion and categorization. }\end{array}$ & 28 & 27 \\
\hline$*$ & $\begin{array}{l}\text { It makes teachers use a variety of } \\
\text { teaching aid which are available in their } \\
\text { environment. }\end{array}$ & 12 & 14 \\
\hline
\end{tabular}

Source: Compiled from field data (2014).

Table 3 indicates that both categories of teachers had similar ranking on the reasons for joining in-service teacher training as follows: In terms of prioritization, first, it enables them to increase salary, promotion and categorization; second, it leads them to develop intellectual skills such inquiry, problem-solving, analysis and synthesis; third, it makes teachers use a variety of teaching aids which are available in their environment; Fourth, it enables them to know how to organize learning groups of different abilities; Fifth, it enables them to design tasks that will address learners' abilities, interests and needs. In this respect, Mbunda (1992) point out that in-service teacher training is always provided in order to upgrade academic as well as professional competencies among teachers. The duration and type of in-service courses, involve residential courses leading to certificates of attendance while others are long-term residential courses that lead to diploma and degree certificates to promote salary increase and knowledge skills.

4.0 Self-initiatives Taken by both Two Types of Teachers to Undergo In-service Training Course

The licensed trained teachers pointed out that there were two reasons that forced them to undergo further studies to up-date their knowledge and skills. First, there was a promise made by MoEST to sponsor those studies for all licensed teachers from the beginning of the program in 2004 to 2009 on conditions that anybody who did not undergo further studies his/her employment would be terminated by the government. Second, the society perceived them as unqualified teachers because of the short training which made them be nicknamed as voda fasta in relation to the Vodacom mobile phone company's advertisement on how fast they can provide their services to their customers when compared to other mobile phone service providers.

However, municipal secondary education officers and headmasters/mistresses reported that licensed trained teachers had more self-initiative in attaining in-service training course than normal trained teachers because the former were given a probation period of five years for up-grading their levels of education, otherwise, they would be terminated from employment. Therefore, it could be concluded that licensed trained teachers were likely to have 
more self-initiative for in-service training than normal trained teachers because normal were not employed under government conditions.

\subsection{Challenges and Problems Facing Licensed and Normal Trained Teachers}

Findings revealed that there were several challenges and problems that face licensed and normal trained teachers in teaching students in their classes. Both licensed and normal trained teachers maintained that their classes were too overcrowded and this led to poor teaching. They argued that increasing number of enrolment for students in form one had brought a negative impact to the teaching profession. All of the schools visited had higher teacherstudent ratio in classroom than that of the national education standard which is 1:40. This made both types of teachers fail to impart knowledge effectively to the students.

Frequent changes in secondary schools curricula had brought a negative impact on the teaching profession. Education curricula had been changing frequently without having any teaching orientation to the teachers. As a result, teachers were appointed to teach subjects without any knowledge of the subject concerned. For example, one of the respondents from headmasters/mistress had the following arguments:

"teachers have been forced to teach certain topics from curricula that were unfamiliar to them and without being given any orientation. This situation is an impediment to respective teachers as regards teaching/learning materials preparations and use”.

On other side of the coin, there was a shortage of teaching and learning facilities in secondary schools which hindered their teaching evaluation. The absence of learning and teaching materials had made teachers to teach students without using teaching aids and sometimes had to look for assistance from neighbouring school in order to improve their teaching profession. For instance, some of the respondents from licensed and normal trained teachers went further to point out that:

"we had to get some academic assistance from our fellow colleagues within the schoolsor from colleagues in the neighbouring schools to help us on how to teach the new curricula or topicsand sometimes, we relied heavily on school inspectors or secondary academic officersfor help."

Their arguments were supported by almost all Municipal Secondary Education Officers who concurred that there was a shortage of teaching and learning facilities in secondary schools which hindered their teaching evaluation. They argued that the absence of learning and teaching materials have forced teachers to teach students without using teaching aids. Both licensed and normal trained teachers pointed out that:

"we had to get some academic assistance from our fellow colleagues within the schools or in the neighbouring schools to help us on how to teach the new curricula or topics and sometime, we relied heavily on school inspectors or secondary academic officers for help".

The above testimonies were concurred by Tanzania Institute of Education (TIE) and MoEST officials who noted out that:

"shortage of teaching and learning materials was a big problem in the schools because teachers had to teach students using their own experience. This made students acquire knowledge and skills in a shallow manner"

In addition, poor working environment was a big challenge that faced both types of teachers in Tanzania. They had no houses for settling in with their families and salaries were not enough to sustain their families. This situation had contributed to the decline of teachers' morale for work as pointed out by one of the respondents from students' parents that:

"the quality of education in Tanzania will decline every year if the government does not improve the living and working conditions for teachers. Teachers are working and living in poor environment, they do not have proper and decent quarters or houses, good salaries and other fringe benefits"

Furthermore, zonal secondary inspectorate officers reported that there was a lot of bureaucracy in releasing teachers from work. They argued that headmasters/ mistresses and municipal secondary school officers had a lot of bureaucracy for releasing their teachers to attend further studies. They argued that teachers applied to join further studies and got admitted but their headmasters/mistresses did not allow unless they had attained five years of employment.

Furthermore, headmasters/mistresses pointed out that those frequent changes in secondary schools curricula had brought a negative impact on the teaching profession. They contended that secondary education curricula had been changing frequently without having any teaching orientation to the teachers. As a result, teachers were appointed 
to teach subjects without any knowledge of the subject matter concerned. For example, one of the respondents had the following arguments:

"teachers have been forced to teach certain topics from curricula that were unfamiliar to them and without being given any orientation. This situation is an impediment to respective teachers as regards teaching/learning materials preparations and use”.

In addition, The heads of schools had it that poor working environment was a big challenge that faces both types of teachers in Tanzania. This situation had contributed to the decline of teachers' morale for work as noted out by one of the respondents from students' parents that:

" the quality of education in Tanzania will decline every year if the government does not improve the living and working conditions for teachers. Teachers are working and living in poor environment, they do not have proper and decent quarters or houses, good salaries and other fringe benefits "

The zonal secondary inspectorate officers reported that there was a lot of bureaucracy in releasing teachers from work. They argued that headmasters/ mistresses and municipal secondary school officers had a lot of bureaucracy for releasing their teachers to attend further studies.

\subsection{General Conclusions}

The study tried to identify clearly the types of in-service teacher training programs offered to both two types of teachers to update and upgrade their knowledge and skills, self-initiatives taken by both two types of teachers to undergo in-service training course, challenges and problems facing them in their daily activities. It can be concluded that apart from student-teachers having the same academic levels, but they differ in how they acquired the knowledge and skills. For example, the licensed trained teachers showed more enthusiasm to upgrading themselves compared to the normal trained teachers. Furthermore, the duration of training program was not equal because licensed trained teachers were taught for three months only while normal trained teachers were taught for two years. This variation of training contributed much to the ineffectiveness of teaching.

\subsection{Recommendations}

Based on the study findings and ensuing conclusion, the following recommendations are made: first and foremost, The MoEST should provide and support general and specific in-service training programs, especially for the crash trained teachers, so that they become more knowledgeable and skilled in the teaching and learning processes. Second, both moral and material incentives should be given to both types of teachers in order to motivate them including improvement of working environment, salaries, teaching allowances and other fringe benefits.

\subsection{Reference}

Clandinin, J., (1995). Teachers’ Professional Land Scales. New York: Lincoln Inc.

Cochran, K., (1993). Pedagogical Context Knowing: An Integrative Model for Teachers Preparation. Journal of Teachers Education. Vol. 44. No. 2. pp 19-32.

Dunn, W., (1981). Public Policy Analysis: An Introduction. Eaglewood Cliff: Prentice Hall.

Dye, I., (1978). Understanding Public Policy. Eaglewood Cliff: Prentice Hall

Galabawa, J. Senkoro, F and Lwaitama, F (2000). The Quality of Education in Tanzania. Dar es Salaam Dares Salaam University Press

Heyneman and Loxley, W., (1983). “'The Effect of Primary School, Quality on Academics Achievement across Twenty Nine High Low Income Countries', In American Journal of Sociology. Vol. 8, No. 3. pp 172-178

Joyce, B., and Showers, B., (1988). Student Achievement through Staff Development. New York: Longman.

Kanu, Y., (1996). Educating Teachers for the Improvement of the Quality of Basic Education in Developing Countries. International Journal of Educational Development. Vol. 16. No. 4. pp 173-184.

Kiwia, S., (1999). The Challenges in Sustaining Literacy Program in Tanzania. Journal of Adult Education. Vol.. No. 5. pp. 26-29 
Linde, G., (1998). In-Service Training of College Tutors. Stockholm: Institute Education Press Page 1-10, University of Dar es Salaam

Mbunda, F (1992). Developing Pedagogical Structure for Improved Learning in the Primary Schools in Tanzania, Basic Education Forum, Basic Education Resource Centre: Kenyatta University.

Meli, B (2014). An Evaluation of Teacher Education and Training in Tanzania, Comparative Study between Licensed and Normal Trained Teachers, A PhD Thesis Submitted to University of Dar es Salaam.

Osaki, K., (1996). The Challenging Forms, Content and Interpretation of Curriculum in Tanzania. Papers in Education and Development. Vol.??? . No 17. pp. 8-19.

Swazin, J., and Monk, M. (2000). Constraints on Development and Changes to Teachers, Practices in Classroom. London: Inc. Press

Trowbridge, L., and Bybee, R., (1996). Teaching Secondary Schools: Strategies for Developing Scientific Literacy. Columbus: Merrill Publishing Company. 